NBER WORKING PAPER SERIES

\title{
LAW AND FINANCE: \\ WHY DOES LEGAL ORIGIN MATTER?
}

\author{
Thorsten Beck \\ Asli Demirgüç-Kunt \\ Ross Levine \\ Working Paper 9379 \\ http://www.nber.org/papers/w9379 \\ NATIONAL BUREAU OF ECONOMIC RESEARCH \\ 1050 Massachusetts Avenue \\ Cambridge, MA 02138 \\ December 2002
}

\begin{abstract}
We thank Pam Gill for excellent research assistance. We thank without implicating Daron Acemoglu, Maria Carkovic, Simeon Djankov, Tim Guinnane, Simon Johnson, Paul Mahoney, Richard Messick, Jean-Laurent Rosenthal, Andrei Shleifer, and two anonymous referees. Parts of this paper were originally part of a working paper titled "Law, Politics, and Finance," which was a background paper for the 2002 World Development Report. This paper's findings, interpretations, and conclusions are entirely those of the authors and do not necessarily represent the views of the World Bank, its Executive Directors, or the countries they represent. The views expressed herein are those of the authors and not necessarily those of the National Bureau of Economic Research.
\end{abstract}

(C) 2002 by Thorsten Beck, Asli Demirgüç-Kunt, and Ross Levine. All rights reserved. Short sections of text, not to exceed two paragraphs, may be quoted without explicit permission provided that full credit, including (C) notice, is given to the source. 
Law and Finance: Why Does Legal Origin Matter?

Thorsten Beck, Asli Demirgüç-Kunt, and Ross Levine

NBER Working Paper No. 9379

December 2002

JEL No. G2, K2, K4, O16, P5

\begin{abstract}
New research suggests that cross-country differences in legal origin help explain differences in financial development. This paper empirically assesses two theories of why legal origin influences financial development. First, the "political" channel stresses that (i) legal traditions differ in the priority they give to the rights of individual investors vis-à-vis the state and (ii) this has repercussions for the development of property rights and financial markets. Second, the "adaptability" channel holds that (i) legal traditions differ in their ability to adjust to changing commercial circumstances and (ii) legal systems that adapt quickly to minimize the gap between the contracting needs of the economy and the legal system's capabilities will foster financial development more effectively than would more rigid legal traditions. We use historical comparisons and cross-country regressions to assess the validity of these two channels. We find that legal origin matters for financial development because legal traditions differ in their ability to adapt efficiently to evolving economic conditions.
\end{abstract}

$\begin{array}{lll}\text { Thorsten Beck } & \text { Asli Demirgüç-Kunt } & \text { Ross Levine } \\ \text { World Bank } & \text { World Bank } & \text { Carlson School } \\ \text { Washington, DC 20433 } & \text { Washington, DC } & \text { of Management } \\ \text { tbeck@worldbank.org } & \text { ademirguckunt@worldbank.org } & \text { University of Minnesota } \\ & & \text { Minneapolis, MN 55455 } \\ & \text { and NBER } \\ & \text { rlevine@csom.umn.edu }\end{array}$




\section{Introduction}

A growing body of work suggests that cross-country differences in legal origin help explain cross-country differences in financial development. La Porta, Lopez-de-Silanes, Shleifer, and Vishny (1998, henceforth LLSV) show that whether a country's Commercial/Company law is based on British, French, German, or Scandinavian legal origins is important for explaining the country's laws on creditor rights, shareholder rights, and private property rights as well as the country's level of bank and stock market development. Subsequent research relates legal institutions to corporate valuations and ownership concentration (LLSV, 2002a; Himmelberg, Hubbard, and Love, 2002), firm's debt maturity structure, access to external finance and growth (Demirguc-Kunt and Maksimovic, 1998, 1999), cross-firm and cross-industry capital allocation (Wurgler, 2000; Beck and Levine, 2002; Claessens and Laeven, 2003), the informational efficiency of stock prices (Morck, Yeung, and Yu, 2000), and financial fragility (Johnson, et al., 2000). Furthermore, Levine (1998, 1999) traces the effect of legal origin on financial development through to long-run economic growth, suggesting that legal origin influences economic growth by shaping national financial systems.

While LLSV and others show that legal origin explains financial development, the profession has not empirically explained why legal origin matters. North (1988), for instance, argues that Britain has better institutions than France does. According to this view, British colonies are likely to inherit better institutions than French colonies with positive ramifications on financial development. Thus, legal origin may proxy for institutions that are not fundamentally related to the legal system. Similarly, Stulz and Williamson (2003) note that British origin countries are primarily Protestant, while French origin countries are overwhelmingly Catholic. They argue that legal origin proxies for religious and cultural differences that influence financial development and that differences in legal tradition, per se, are not crucial for explaining current levels of financial development. Beck, 
Demirguc-Kunt and Levine (2003), however, show that legal origin remains robustly linked with financial development when controlling for religious composition and other national characteristics. ${ }^{1}$ While legal origin is robustly linked with financial development, the literature has not shown the channels via which legal origin shapes finance. Consequently, this paper (1) discusses and empirically assesses two theories of why legal origin matters for financial development and (2) assesses whether legal origin explains financial development only through these two channels.

Legal theories emphasize two inter-related channels through which legal origin influences finance. First, the "political" channel contends that (a) legal traditions differ in terms of the priority they attach to private property rights versus the rights of the State and (b) the protection of private contracting rights forms the basis of financial development (LLSV, 1999). According to this view, the English common law evolved to protect private property owners against the crown. This facilitated the ability of private property owners to transact confidently, with positive repercussions on financial development (North and Weingast, 1989). In contrast, the political channel holds that the French and German civil codes in the $19^{\text {th }}$ century were constructed to solidify State power by placing the "prince above the law" (Hayek, 1960, 166-7). ${ }^{2}$ Over time, State dominance of the judiciary produced legal traditions that focus more on the power of the State and less on the rights of individual investors [Mahoney, 2001]. More generally, the political channel stresses that the civil law tradition promotes the development of institutions that advance State power with adverse implications on financial development. Thus, the political channel highlights the degree to which the State controls the judiciary and emphasizes the difference between common and civil law countries.

Second, the "adaptability" channel stresses that (a) legal traditions differ in their ability to evolve with changing conditions (Hayek, 1960) and (b) legal traditions that adapt efficiently to minimize the gap between the contracting needs of the economy and the legal system's capabilities 
will more effectively foster financial development than more rigid systems (Merryman, 1985). An influential, though not unanimous, strand of the comparative law literature holds that the Common law evolves efficiently as judges respond case-by-case to unforeseen and changing conditions (Posner, 1973). ${ }^{3}$ Several scholars argue that since the Common law grants substantial discretion to judges, inefficient laws are challenged in the courts and through repeated litigation efficient rules replace inefficient ones. ${ }^{4}$ These authors suggest that legal systems that (i) reject jurisprudence - the law created by judges in the process of solving disputes - and (ii) rely instead on changes in statutory law will tend to evolve more inefficiently with negative implications for finance.

In a corollary to the adaptability view, Dawson (1968) and Merryman (1996) advance the "French Deviation" view, which distinguishes many French law countries from France and German law countries. According to this view, the French Revolution sought to change French law radically by eliminating jurisprudence. Under Napoleonic legal doctrine, judges simply apply the law; judges do not interpret the law, the principle of stare decisis is rejected (Merryman, 1996, 111-112). Dawson (1968) and Merryman $(1985,1996)$ consider this a radical deviation because prior to the Revolution, jurisprudence was an important source of French law. Since Napoleonic legal doctrine did not work well in practice and conflicted with France's long legal history, the French courts circumvented the doctrine. "What the judges actually did, however, was build a body of law based to some extent on earlier French law, nourished by French legal scholarship, but built largely through their own decisions" (Merryman, 1996, 113). Unfortunately for French colonies, “...when the French exported their system they did not include the information that it really does not work that way, and they failed to include a blueprint of how it actually does work" (Merryman, 1996, 116). Thus, unlike France, many French civil law colonies have been unable to shake off the shackles of the Napoleonic doctrine. Critically, Germany explicitly rejected the French deviation. Building on 
Savigny's vision of legal science, Germany accepted the need for jurisprudence and sought to create a responsive legal doctrine. Adopters of the German code, therefore, obtained a legal system specifically designed to evolve with changing conditions. According to this corollary, many French civil law countries will have more rigid legal systems and therefore support financial development less effectively than German civil law countries, Common law countries, and France itself.

While the political and adaptability channels are inter-related parts of the law and finance theory and while they both predict that legal origin shapes financial development, they emphasize different mechanisms. The political channel focuses on the power of the State. Legal traditions that strengthen the power of the State relative to private property rights tend to hinder the development of free, competitive financial markets. In contrast, the adaptability channel focuses on the process of law making. Legal traditions that efficiently adapt to changing conditions, by eliminating inefficient laws and creating more efficient ones, support financial development to a greater degree than more rigid legal systems. Of course, legal origin may operate through both channels; the political and adaptability channels are not mutually exclusive. We empirically assess the importance of each channel in accounting for cross-country differences in financial development.

Although there are differences between the political and adaptability channels, they are interconnected parts of the law and finance approach to financial development and it may not be feasible to distinguish fully between these two mechanisms. Specifically, the political channel focuses on the power of the State while the adaptability channel highlights differences in the ability of legal systems to evolve with changing conditions. Jurisprudence, however, may be much less likely in a system where the State controls the judiciary than in a system where the judiciary enjoys greater independence (Damaska, 1986; Glaeser and Shleifer, 2002). This may lead to skepticism regarding the ability to distinguish the independent effects of the political and adaptability channels. Moreover, 
since we only have imperfect empirical proxies of State control of the judiciary and legal system adaptability, this aggravates the identification problem. While recognizing these barriers to assessing the comparative roles of the political and adaptability channels, we continue with our investigation using the best available data.

This paper is related to recent research on the operation and evolution of legal systems. La Porta et al. (2002b) shows that the independence of the judiciary and jurisprudence are closely associated with economic freedom. We, however, focus on the channels through which legal origin influences finance. In related work, Pistor et al. (2000, 2003) and Keinan (2000) provide detailed comparisons of the evolution of statutory corporate law and the law on secured transactions in key countries. In contrast, our paper uses broad cross-country regressions to assess whether legal tradition shapes finance primarily by affecting the power of the State relative to the judiciary or primarily by influencing the adaptability of the law to evolving conditions. Finally, Djankov et al. (2003) collects detailed data on the operation of legal systems. They examine the link between legal origin and the operation of legal systems and assess the association between the operation of legal systems and corruption. We exploit data constructed by La Porta et al. (2000b) and Djankov et al. (2003) to form proxies of (i) the power of the State over the judiciary and (ii) the degree of legal system adaptability and then study whether legal origin influences finance through the political and adaptability channels. Specifically, we use legal origin dummy variables as instrumental variables, compute the exogenous component of State control over the judiciary and legal system adaptability, and assess through which channel legal origin influences financial development.

The remainder of the paper is organized as follows. Based on the comparative law literature, section 2 discusses the political and adaptability channels. Section 3 describes the data and section 4 presents the results from cross-country regressions. Section 5 concludes. 


\section{The Political and Adaptability Channels of the Law and Finance Theory}

\subsection{The Political Channel: Historical Background}

In the sixth century, Emperor Justinian had Roman law compiled. Hayek (1960) notes that the Justinian texts represent an important break with Roman law. While Roman law placed the law above all individuals, the Justinian texts place the emperor above the law.

From the 1400s, France's legal system progressed as a regionally diverse mélange of customary law, Justinian's legal texts, and judicial decisions. Further, by the $18^{\text {th }}$ century, the judiciary's reputation had deteriorated as the monarch sold judgeships to rich families. These families used their control of the courts to impede progressive reform and support their own interests.

Unsurprisingly, the French Revolution turned its fury on the judiciary and moved to eliminate the role of the judge in making and interpreting the law. Robespierre even argued that, "the word jurisprudence ... must be effaced from our language.” (Dawson, 1968, p. 426). France sought liberty and progressive reform by creating a strong legislature and by limiting judicial independence. Consequently, in codifying the Code, Napoleon - like Justinian - (a) unified regional legal systems and (b) placed the State above the courts. Thus, codification supported the unification and strengthening of the government and relegated judges to a relatively minor bureaucratic role.

Like Napoleon, Bismarck unified Germany and its legal systems through codification. Although Bavaria and Prussia codified parts of the law during the $18^{\text {th }}$ century, it was Bismarck's decision in 1873 to codify and unify the whole of private law in Germany that led to the adoption of the German civil law in 1900. Thus, according to the political channel, Bismarck's codification like Justinian and Napoleon before him - consolidated and strengthened the state. 
The history of the English common law is very different. The English common law attained its modern form in the tumultuous $16^{\text {th }}$ and $17^{\text {th }}$ centuries when Parliament and the English kings battled for control of the country. The Crown attempted to reassert feudal prerogatives and sell monopolies to raise revenues. Parliament (composed mostly of landowners and wealthy merchants), together with the courts took the side of property owners. Ultimately, the Crown was unable to reassert feudal privileges and its ability to grant monopolies was also severely restricted. The courts asserted that the law is king and limited the Crown's discretion to alter property rights. Thus, in comparison with France during the $16^{\text {th }}$ and $17^{\text {th }}$ centuries, the English common law was a source of liberty and a champion of private property rights.

\subsection{The Political Channel}

The political channel holds that (i) legal traditions differ in their emphasis on the rights of private property owners vis-à-vis the rights of the State and (ii) private property rights form the basis of financial development. Thus, historically determined differences in legal origin help explain existing differences in financial development (LLSV, 1998).

The political channel argues that the Civil law has tended to emphasize the rights of the State, rather than private property rights, to a greater degree than the common law with adverse implications for financial development. Indeed, LLSV (1999, 231-2) state that, “(A) civil legal tradition, then, can be taken as a proxy for an intent to build institutions to further the power of the State..." A powerful State will tend to create policies and institutions that divert the flow of society's resources toward favored ends, which is antithetical to competitive financial markets. Furthermore, a powerful State with a responsive civil law at its disposal will have difficulty credibly committing to not interfere in financial markets, which will also hinder financial development. 
In contrast, the political channel argues that the Common law historically stood on the side of private property owners against the State. Rather than becoming a tool of the State, the Common law has acted as a powerful counterbalance that has promoted private property rights. Thus, according to the political channel, the common law's comparative emphasis on private property rights relative to the State tends to support financial development to a greater degree than the civil law. ${ }^{5}$

\subsection{The Adaptability Channel: Historical Background}

Not only did Justinian's codification break with the Roman law tradition by placing the emperor above the law; Justinian also broke with the Roman law tradition by attempting to eliminate jurisprudence. Roman law had evolved from a law for a small community of farmers to support the needs of an imperial city through piecemeal case-made law over many centuries. Justinian attempted to change this doctrine and “ $\ldots$ asserted for himself a monopoly, not only over all law-making power, but over legal interpretation." (Dawson, 1968, p. 122) Nevertheless, this "Justinian deviation" did not take root; jurisprudence continued to shape the law. Thus, an essential attribute of Europe's legal tradition, including that in Germany and pre-Revolutionary France, is that it is dynamic, unfinished, and changing (Dawson, 1960; 1968).

In pre-Revolutionary France, judge-made law was an important source of law. Clearly courts must have weighed and debated the appropriate application of conflicting Roman law, customary law, and case law as new circumstances and cases emerged. Yet, from the $14^{\text {th }}$ century onward, judicial deliberations occurred in comparative secrecy. Historically and still today, French courts give remarkably cryptic explanations of their decisions when compared to German or British courts (Dawson, 1968, p. 286-311).

As noted above, the French Revolution sought to make the law judge-free (Merryman, 1996). The theory underlying the French legal doctrine is that the legislature drafts laws without gaps, so 
judges do not make law by deciding cases. The theory is that the legislature does not draft conflicting laws, so judges do not make law by choosing among competing statutes. The theory is that the legislature provides clear laws, so judges do not make law by giving practical meaning to ambiguous laws. The theory is that judges play a mechanical role. Like Justinian, Napoleon sought a code that was so clear, complete, and coherent that there would be no need for judges to deliberate publicly about which laws, customs, and past experiences apply to new situations.

While Revolutionaries sought to eliminate jurisprudence, Merryman $(1985,1996)$ argues that the French have found ways to circumvent many of the inefficient qualities of the Napoleonic doctrine over the last two centuries. Indeed, the lead draftsmen of the Code recognized that the legislature could not draft complete, fully consistent, and comprehensive codes. Practitioners recognized that the legislature could not revise the Code sufficiently rapidly to handle efficiently the myriad of changing problems that arise in a dynamic nation. Consequently, in contrast to doctrine, the French courts eventually built an entire body of tort law on the basis of Article 1382 of the Code Napoleon that states that one whose act injures another must compensate that person. In contrast to doctrine, French courts have recently used case law to recast the law of unjust enrichment, alter the law on obligations, re-work the law of contract regarding gifts, and change the system of administrative law (Dawson, 1968, 400-415). Thus, Merryman $(1985,1996)$ argues that the Napoleonic doctrine is a "deviation" from two thousand years of legal tradition built on jurisprudence and judicial discretion.

According to Merryman (1996), however, the exportation of the Napoleonic doctrine has crippled the judicial systems of many French Civil code colonies and reduced the probability that they would develop efficiently adaptive legal systems. There are four inter-related reasons for this assertion. First, the French, unlike the English, rigidly imposed the Code Civil in its colonies even 
though there were - and remain -- serious conflicts between the Code and local laws (ZK, 1998, 10913; henceforth ZK). ${ }^{6}$ Tensions between local law and the transferred doctrine may impede the efficient development and application of the law. ${ }^{7}$ Second, when the French instilled the Code, they brought the theory of the Napoleonic doctrine with its antagonism toward judges, jurisprudence, and judicial discretion. They did not also bring the practical knowledge of how to circumvent some of the negative attributes of the Code and reinstall an efficient role for judges. Third, given the Napoleonic doctrine, judges "... are at the bottom of the scale of prestige among the legal professions in France and in many nations that adopted the French Revolutionary reforms, and the best people in those nations accordingly seek other legal careers" (Merryman, 1996, p. 116). Consequently, it is more difficult to develop efficiently responsive legal systems if the courts do not attract the best minds. Fourth, France has a long history of avoiding open disputes about legal interpretation (Dawson, 1968). Moreover, Napoleonic doctrine formally inhibits open disputations by judges on how they weigh competing statutes, ambiguous laws, and past court decisions in deciding new cases. The exportation of this characteristic to French Civil code colonies, i.e., the absence of a legal culture of openly discussing the application of the law to evolving conditions, hindered the development of efficient legal systems around the world according to this view. In sum, many argue that French Civil code colonies inherited a restrictive legal doctrine under particular conditions that enhance the probability that their legal system will be less flexible than Common and German civil law countries.

The comparative law literature notes that German legal history is very different from France's. Unlike in France, from the $16^{\text {th }}$ century, German courts published comprehensive deliberations that illustrated how courts weighed conflicting statutes, resolved ambiguities, and tackled new situations (Dawson, 1968). Law faculties at universities worked directly with courts to decide cases and then worked to rationalize reality with the logic of the Justinian texts. Through 
active debate and interchange between scholars and practitioners, Germany developed a dynamic, common fund of legal ideas that formed the basis for codification in the $19^{\text {th }}$ century.

In contrast to the revolutionary zeal and antagonism toward judges that shaped the Napoleonic Code, Germany explicitly rejected the static approach adopted by the French. Unlike the French Code, the German Code "was not intended to abolish prior law and substitute a new legal system. On the contrary, the idea was to codify those principles of German law that would emerge from careful historical study of the German legal system.” (Merryman, 1985, p. 31) The German civil code embraced the need for jurisprudence in creating a responsive, flexible legal system.

The English common law tradition is almost synonymous with judges having broad interpretation powers and with courts molding and creating law as circumstances change. The common law is obsessed with facts and deciding concrete cases, rather than adhering to the logical principles of codified law. Thus, the popular dictum: "The life of the law has not been logic: it has been experience." (ZK, 1998, p. 181). Unlike the Napoleonic doctrine, judges continually - and as a matter of general practice -- shape the law through their decisions.

\subsection{The Adaptability Channel}

The adaptability channel is built on two basic premises. First, to the extent that a legal system adapts slowly, large gaps will appear between financial needs and the legal system's ability to support those needs. Second, the major legal traditions differ in terms of their ability to adapt to changing financial circumstances.

According to the adaptability channel, legal systems that embrace case law and judicial discretion tend to be more responsive to changing economic conditions than legal systems that rely more strictly on judgments based purely on statutory law (Posner, 1973). Inefficient laws are challenged in the courts and "... through the process of litigation and re-litigation inefficient rules will 
be replaced by efficient rules" (Pistor et al., 60, 2000; See Rubin, 1977; Priest, 1977). In contrast, legal systems that reject jurisprudence necessarily rely more on statutory law changes to modernize and adapt the law. A large legal literature, however, argues that statutory law is slow and costly to change, so that the absence of jurisprudence tends to hinder the efficiency with which laws adapt to changing conditions (Bailey and Rubin, 1994). ${ }^{8}$

The adaptability channel predicts that French legal origin countries, albeit not necessarily France itself, have a lower probability of having an efficiently flexible legal system than German civil law and especially Common law countries.

The first and main argument focuses on jurisprudence and not adhering too rigidly to statutory law. The adaptability channel holds that the Common law is inherently dynamic as it responds caseby-case to the changing needs of society. This limits the opportunities for large gaps to grow between the demands of society and the law. In contrast, the Napoleonic doctrine's distrust of judges and jurisprudence has hindered the flexibility of the legal system in many French law countries, with adverse implications on financial development. Furthermore, many legal scholars argue that the German law falls close to the Common law in terms of adaptability since it rejected the Napoleonic doctrine and instead maintained its historical roots in jurisprudence and judicial discretion. As noted, Merryman (1985) argues that France did not adhere to its legal doctrine and instead re-instilled jurisprudence. French Civil code colonies were not so lucky, however. When the French rigidly imposed the Code, they imposed the Napoleonic doctrine and did not necessarily include a blueprint of how it actually should work. According to this view, French civil law countries have a lower probability of enjoying an efficiently flexible legal system than Common or German civil law countries. 
Two other characteristics of French law may also work to inhibit the efficient responsiveness of the law to changing financial conditions, especially in former French Civil code colonies. First, Dawson (1968) emphasizes that extensive deliberations about interpreting the law have been key characteristics of German legal history and an inherent part of the Common law, but France has historically exhibited a dislike of open judicial disputations. Furthermore, the Napoleonic doctrine that was exported internationally prohibits these disputations. According to the adaptability channel, legal cultures that discourage open deliberations about the applicability and interpretation of the law will hinder the development of efficiently dynamic legal systems.

Second, Merryman (1996, p. 116) argues that the most powerful consequence of the Napoleonic doctrine "... may have been to demean judges and the judicial functions." According to the Napoleonic doctrine, judges served a mainly clerical function. Thus, in France and French law countries, recruiting practices, salaries, and prestige frequently reflect this perspective. According to this view, the Napoleonic doctrine became self-fulfilling: the best minds chose other professions, which hindered efficient legal flexibility. As a consequence, the legislature will have a tendency to write "bright line laws" to limit the role of the courts. "Once this pattern of lawmaking has been established, however, it is hard to change" (Pistor et al., 2000, 62). Courts will not be challenged to develop legal procedures and methods to deal with emerging conditions. Thus, according to some scholars, these characteristics of the French law have worked to retard the development of efficiently adaptive legal systems that support financial development.

\subsection{An Aside on France vs. Germany}

Though not central to our analysis, some scholars emphasize the greater adaptability of the German relative to French law beyond former French colonies. ${ }^{9}$ Consider for instance the assignment of contracts. Roman law started from the position that personal rights could not be 
transferred. Over the centuries, customary law in (what is now) Germany evolved to support a wide range of financial assignments as transferability of financial claims became an important part of commercial arrangements. Ultimately, the courts held that assignment was complete once the assignor and assignee agreed. In both Germany and the United Kingdom, the principle of assignment was developed by court decisions before it was codified into the German BGB (1900) and the UK's Judicature Act (1873). In French law, however, the assignment is only treated as complete if the original debtor is notified, which has potentially negative implications for asset transferability. While the French legislature has revised certain statutes to circumvent the obsolete rules contained in the Code, the more flexible structure of the German and Common law allowed business to more efficiently assign debts (ZK, 135; 442-455, 1998). A similar pattern of jurisprudence is found in the law on contracts for the benefit of third parties, e.g., insurance contracts, annuity arrangements, etc. (ZK, 456-469). Interestingly, the German courts used the law regarding third parties to fill gaps in tort law during the twentieth century, which further illustrates the flexibility of German courts. Similarly, it was the German courts, not the legislature that took the lead in affording protection against unfair conditions of business during the $20^{\text {th }}$ century. As noted by ZK $(1998,336)$, "What we have here is judge-made law of the purest kind." While typical in Common law courts and Germany, some argue that this type of judge-made law would be considered more aberrant in a French system.

\subsection{Differences between the Political and Adaptability Channels}

The political and the adaptability channels make conflicting predictions. First, they provide conflicting predictions regarding French versus German civil law countries. The political channel holds that the Civil law tradition - both French and German - tends to centralize and intensify state power and therefore takes a more wary stance toward the development of free financial systems than 
the Common law. In contrast, the adaptability channel stresses that Common law and German civil

law countries have notably more adaptable legal traditions than French civil law countries. ${ }^{10}$

Second and more importantly for our purposes, the two channels make different predictions concerning the mechanism through which legal systems influence the development of financial markets. The political channel contends that State control of the judiciary produces a system that focuses more on the power of the State and less on the private contracting rights of individual investors than a legal system characterized by an independent judiciary. Thus, the political channel stresses that cross-country differences in the independence of the judiciary are critical for explaining cross-country differences in financial development. In contrast, the adaptability channel stresses that cross-country differences in the flexibility of the law are critical for explaining cross-country differences in financial development. We empirically assess these hypotheses below.

\section{Data}

We use cross-country analyses to assess the empirical validity of the political and adaptability channels. We examine a sample of up to 115 countries with French Civil, German Civil, Scandinavian Civil and British Common Law origins. Due to data limitations on the political and adaptability indicators, however, the sample is reduced to 54 countries in some of the regressions.

Our data include origin countries, which raises the question of endogeneity. Berkowitz et al. (2002) stress the difference between legal origin countries - U.K, U.S., France, Germany, Austria, Switzerland and the five Scandinavian countries - which formed legal traditions, and the transplant countries, which received the legal traditions. This is less of an issue in our analysis since the legal origin variables are primarily used as instrumental variables and we use specification tests to assess 
the validity of the instruments. Nevertheless, we have confirmed all of the results in the paper using a smaller sample of countries that eliminates the eleven countries listed above.

To assess the political and adaptability channels empirically, we need indicators of financial development, legal origin, State power over the judiciary, and the adaptability of a legal system. We describe these variables in turn. Table 1 presents descriptive statistics and correlations.

\subsection{Financial Development}

To measure financial development, we use indicators of financial intermediary development, stock market development, and the protection of property rights. There is no single, universally accepted measure of financial development. As noted in Levine (1997), financial systems arise to mitigate information and transaction costs and thereby enhance the allocation of capital. Different types and combinations of information, enforcement, and transaction costs in conjunction with different legal, regulatory, and tax systems have motivated distinct financial contracts, markets, and intermediaries across countries and throughout history. Since there are different ways to organize financial systems - sometimes through banks, sometimes through markets, sometimes through private contracts - we use three alternative but complementary measures of financial development. We use the same indicators as in Beck, Demirguc-Kunt, and Levine (2003).

Private Credit equals financial intermediary credits to the private sector divided by gross domestic product (GDP) and is measured over the 1990-95 period. Private Credit excludes credit to the public sector and cross claims of one group of intermediaries on another. It thus measures the amount of savings that is channeled through debt-issuing financial intermediaries to private borrowers. King and Levine (1993a,b) and Levine, Loayza, and Beck (2000) show a strong connection between measures of banking sector development and economic growth. The summary statistics in Table 1 shows a wide variation in Private Credit, ranging from over $140 \%$ of GDP in the 
United States, the Netherlands, Japan and Switzerland to less than 5\% in Sudan, Ghana, Guinea, Sierra Leone, Uganda, Angola, and Congo (Zaire).

Stock Market Development equals the total value of outstanding equity shares as a fraction of GDP and is averaged over the 1990-95 period. This measures the overall size of the equity market relative to the size of the economy. Levine and Zervos (1998) and Beck and Levine (2003) show that stock market development is positively associated with economic growth even after controlling for the level of banking sector development. Beck, Demirguc-Kunt, and Levine (2003) note that equity market transactions tend to rely more than banking institutions on well-functioning legal systems to defend the rights of individual investors. From this perspective, we may expect to find a closer connection between legal origin and stock market development than between legal origin and banking sector development. While Malaysia has a market capitalization of $189 \%$ of GDP, there are 42 countries in our sample with no measurable stock market activity.

Property Rights is an index of the degree to which the government protects private property and enforces laws that protect private property. The data are for 1997 and were obtained from LLSV (1999) and the Index of Economic Freedom. While Private Credit and Stock Market Development are direct measures of the size of financial intermediaries and equity markets, Property Rights measures a key input into the efficient operation of financial contracts and the development of formal financial institutions: the degree of protection of private property rights. The maximum value of Property Rights is five, while one indicates the weakest property rights protection. Twenty-five countries have the highest degree of property right protection, while three countries have little or no protection at all (Property Rights equals one). 
The correlation matrix in Table 1, Panel B shows that all three measures of financial development are highly correlated with each other. The lowest correlation coefficient is 0.52 and the correlations are significant at the 1 per cent level.

\subsection{Legal Origin}

Through occupation, colonization and imitation, the British, French and German legal origin spread around the world. Napoleon made it a priority to secure the adoption of the Code in all conquered territories, including Italy, Poland, the Low Countries, and the Habsburg Empire. Also, France extended her legal influence to parts of the Near East, Northern and Sub-Saharan Africa, Indochina, Oceania, French Guyana, and the French Caribbean islands during the colonial era. Furthermore, the French Civil Code was a major influence on the Portuguese and Spanish legal systems, which helped spread the French legal tradition to Central and South America. The British exported the Common law through its colonies. The Austrian and Swiss civil codes were developed at the same time as the German civil code and the three influenced each other heavily. The German Civil Code was not imposed but exerted a big influence on China (and hence Taiwan), Czechoslovakia, Greece, Hungary, Japan, Korea, and Yugoslavia.

We use data from LLSV $(1998,1999)$ that identifies legal origin of each country's Company/Commercial Law. Thus, the British Legal Origin dummy variable equals one if the country adopted its Company/Commercial law from the British Common Law and zero otherwise. A similar rule is followed for the other legal origin dummies. Our sample comprises 43 countries with British Common Law, 61 countries with French Civil Law, six countries with German Civil Law and five Scandinavian Civil Law countries. The correlation analysis indicates that countries with French Civil Law have significantly lower levels of Private Credit, Stock Market Development and Property 
Rights than countries with German, Scandinavian, or British legal origins. German legal origin countries have higher levels of financial development.

\subsection{Indicators of the Political Channel}

Our two indicators of the relative power of the judiciary vis-à-vis the executive and legislature are from La Porta, Lopez-de-Silanes, Pop-Eleches, and Shleifer (2002b).

Tenure of Supreme Court Judges ranges from zero to two, increasing in the tenure of the Supreme Court judges. If tenure is for less than six years, then this variable is coded as zero. If tenure is between six years and lifelong, then the Tenure of Supreme Courts Judges variable is coded as one. If Supreme Court judges have lifelong tenure, then the variable is coded as two. In a legal system that grants tenure to Supreme Court judges, this increases the independence of the judiciary

relative to the State. According to the political channel, (a) Civil law countries are less likely to grant tenure to judges than Common law countries and (b) larger values of Tenure of Supreme Court Judges will be positively associated with financial development.

The correlations are not fully consistent with the political channel's predictions (Table 1). While countries with a British common law tradition are more likely to grant Supreme Court judges longer tenure than French civil law countries, there is not a significant correlation between German legal origin and the Tenure of Supreme Court judges. Furthermore, Tenure of Supreme Court Judges is not significantly correlated with the financial development indicators.

Supreme Court Power combines the tenure of Supreme Court Judges with a dummy variable indicating whether the Supreme Court has power over administrative cases, i.e. cases involving the government. Thus, Supreme Court Power equals one if (1) Supreme Court Judges have lifelong tenure and (2) the Supreme Courts has power over administrative cases and equals zero if either of these two conditions does not hold. To the extent that the Supreme Court is independent of 
the government as measured by lifelong tenure and has control over cases involving the government, this represents greater judicial power relative to the State. The political channel predicts that Supreme Court judges who have life-long tenure and power over administrative cases are more independent from the State, with positive repercussions for financial and institutional development.

The correlations indicate that British legal origin countries have the highest levels of judicial independence while French civil law countries have the lowest levels of Supreme Court Power. There is not a significant relationship between German legal heritage and Supreme Courts Power. Supreme Court Power is not significantly correlated with the financial development indicators.

\subsection{Indicators of the Adaptability Channel}

We use two variables indicating the extent to which judicial decisions are based (i) on previous court decisions and (ii) on principles of equity rather than on statutory law.

Case Law (La Porta, Lopez-de-Silanes, Pop-Eleches, and Shleifer, 2002b) is a dummy variable that indicates whether judicial decisions are a source of law. The adaptability channel predicts that (a) Common law and German civil law countries are more likely to admit judicial decisions as a source of law than French civil law countries and (b) countries in which judicial decision are a source of law will adapt more easily to changing economic and financial circumstances and therefore have higher levels of financial development. Unsurprisingly, British common law countries have high levels of Case Law, while French civil law countries tend not to include judicial decisions as a source of law.

Legal Justification (Djankov, La Porta, Lopez-de-Silanes and Shleifer, 2003) indicates whether judgments have to be based on statutory law rather than on principles of equity. ${ }^{11}$ Legal Justification takes on values of $0,0.33,0.67$, and 1 , where higher values signify the legal system imposes greater requirements that judgments be based on statutory law. Consistent with the 
adaptability channel, many British Common law legal systems (e.g., Australia, Canada, Ghana, New Zealand, Malaysia, United Kingdom, and United States) have comparatively low Legal Justification requirements (e.g., values of 0 or 0.33 ), where practically all French civil law countries have Legal Justification requirements of either 0.67 or 1 . The adaptability channel predicts that higher values of Legal Justification will be associated with lower levels of financial development.

The Table 1, Panel B correlations are broadly, though certainly not overwhelmingly, consistent with the adaptability channel. Greater adaptability is measured by higher values of Case Law, and lower values of Legal Justification. First, British legal origin countries have the most adaptable legal systems and French legal origin countries have the least adaptable legal systems. There is not a significant correlation between the German legal origin dummy and either of the adaptability indicators. Second, the adaptability indicators are generally significantly correlated with financial development. That is, greater adaptability is positively associated with financial development. Third, as suggested in the Introduction, the adaptability indicators are significantly correlated with the political power indicators.

\subsection{Other Possible Determinants of Financial Development}

To assess the robustness of our results, we include several other potential determinants of financial development in our empirical analysis. Latitude equals the absolute value of the latitude of the country to control for geographic endowments. We take the data from LLSV (1999). In previous work (Beck, Demirguc-Kunt, and Levine, 2003) we have shown that Latitude helps explain financial development. ${ }^{12}$ Independence equals the fraction of years since 1776 that the country has been independent. We include this since a longer period of independence may provide greater opportunities for countries to develop institutions, policies, and regulations that are conducive to open and competitive financial markets. 


\section{Cross-Country Regressions}

This section presents the results from cross-country regressions to assess (1) the importance of legal origin in explaining cross-country variance in financial development, (2) the ability of legal origin to explain cross-country differences in the political and adaptability indicators, and (3) the ability of the exogenous component of the political and the adaptability channels to account for crosscountry differences in financial development.

\subsection{Legal Origin and Finance}

The results in Table 2 show that distinguishing countries by legal origin helps explain crosscountry differences in financial intermediary development, stock market development, and the degree of private property rights protection. This finding was first documented by LLSV (1998) and recently confirmed with additional robustness checks (Beck, Demirguc-Kunt, and Levine, 2003). Even after controlling for geographic endowments and the length of national independence, the legal origin dummies enter jointly significantly in all regressions at the $1 \%$-level. Also, note that Latitude and Independence both enter significantly and positively in most of the regressions.

The results also indicate that French legal origin countries, on average, have substantially lower levels of financial development than German civil law and British common law countries. The superscript "F" on the British legal origin dummy variable indicates that the British legal origin dummy is significantly different from the French legal origin dummy. Similarly, the "B" on the French legal origin dummy, indicates that the French dummy is significantly different from the British Common law dummy, and so forth. As shown, the British legal origin dummy is always significantly larger than the French dummy and the German dummy is significantly greater than the 
French dummy in all regressions except one. In half of the regressions, the German and British legal dummies are not statistically different from each other, while the German legal dummy is significantly greater in the other three regressions. This occurs particularly when using the financial development indicator most closely associated with bank development, Private Credit.

These findings are broadly consistent with the adaptability channel. Recall, the political channel focuses on the difference between the Common law and the Civil law. Thus, the political channel does not predict that German civil law countries will have higher levels of financial development than French civil law countries. The adaptability channel focuses on the distinctly static nature of the French civil law, relative to both the British common and German civil law traditions. Thus, the adaptability channel is consistent with the finding the French civil law countries have notably lower levels of financial development than the other legal families. These results, however, do not reject the political channel since legal origin may operate through both channels.

\subsection{Legal Origin and the Political and the Adaptability Channels}

Table 3 assesses whether legal origin explains cross-country differences in the indicators that we use to define the political and adaptability channels. Thus, we regress the proxies for the political and adaptability channels on the legal origin dummy variables. There are four regressions: two political channel indicators and two adaptability indicators. We report the F-tests of whether the legal origin dummy variables significantly explain cross-country variation in the political and adaptability indicators. We also report cross coefficient tests, as in Table 2, of whether the coefficients on the legal dummies are significantly different from each other.

Legal origin helps explain cross-country variation in the political and adaptability indicators. The F-test of the joint significance of the origin dummies indicates that legal origin enters all of the regressions significantly at the 0.01 level. 
Consistent with the law and finance theory, the Table 3 results indicate that British common law countries have significantly greater judicial independence (i.e., less State control over the judiciary) and significantly more adaptable legal systems than French legal origin countries. Specifically, the tenure of Supreme Court judges and their ability to control administrative cases are all, on average, greater in British common law countries. Similarly, the use of case law and the ability to use equity rather than statutory law in making judgments are, on average, greater in British common law countries.

The Table 3 results are broadly consistent with both the political and adaptability channels. Consistent with the political channel, the civil law countries have significantly less tenure for Supreme Court judges and significantly less judicial control over administrative cases than Common law countries (see the political indicator regressions in Table 3 Panel A), i.e., consistent with the political channel civil law countries tend to foster the power of the State vis-à-vis the judiciary. Further, there are no significant differences between French and German Civil law countries.

Consistent with the adaptability channel, the main difference is between French civil law and British common law countries, not between civil and common law per se. The coefficient on the German legal origin dummy always lies between the French and British coefficients and is significantly different from the French value in the case of Case Law. These results broadly confirm the predictions of the adaptability channel that French civil law countries are less adaptable than both Common and German Civil Law countries.

\subsection{The Political Channel and Financial Development}

Table 4 assesses the questions (a) does the exogenous component of the political indicators explain financial development and (b) does legal origin explain financial development through some 
other mechanisms besides the political channel. To make this assessment, we use two-stage least squares regressions with heteroskedasticity-consistent standard errors of the following form:

$$
\begin{array}{lll}
1^{\text {st }} \text { Stage: } & \text { Political Channel Indicator } & =\delta[3 \text { Legal Origin Dummies }]+\gamma \mathrm{X}+\mathrm{v} \\
2^{\text {nd }} \text { Stage: } & \text { Financial Development } & =\alpha[\text { Political Channel Indicator }]+\beta \mathrm{X}+\mathrm{u}
\end{array}
$$

$\mathrm{X}$ is a set of exogenous variables that are included in some of the second stage regressions. The error terms in the first and second stage regressions are $v$ and $u$, respectively. The three Legal Origin Dummies are the instrumental variables. Thus, the coefficient on the Political Channel Indicator, $\alpha$, provides information on whether State power over the judiciary influences financial development after controlling for potential endogeneity, thus providing the answer to our first question. The test of the overidentifying restrictions (OIR) addresses the second question: Does legal origin explain financial development through some other mechanisms besides the political channel? The null hypothesis of the OIR test is that the legal origin dummies are not correlated with $\mathrm{u} .{ }^{13}$ Thus, rejection of the OIR test is a rejection of the view that the legal origin only explains financial development through the political channel. For the case where the regressions include, X, i.e., the second-stage includes Latitude and Independence, the OIR test becomes a general specification test of the validity of the instruments. We include $\mathrm{X}$ to assess the robustness of the findings by controlling for other potential exogenous determinants of financial development.

The results in Table 4 do not support the political channel. First, the indicators of the political channel do not enter any of the regressions significantly. Second, the OIR-tests are rejected in all regressions, suggesting that legal origin explains financial development through some mechanism besides the political channel. While some may view these results as representing an indictment of the political channel indicators, the legal origin dummies help explain cross-country differences in the 
political channel indicators in a manner that is consistent with theory (Table 3), but the exogenous component of the political channel does not explain finance.

\subsection{The Adaptability Channel and Financial Development}

Table 5 assesses the questions (a) does the exogenous component of the adaptability indicators explain financial development and (b) does legal origin explain financial development beyond the adaptability indicators. To make this assessment, we use the same two-stage least squares methodology described above.

The results in Table 5 provide qualified support for the adaptability channel. First, the adaptability indicators enter significantly and with the correct sign in 10 of the 12 regressions when using a 0.05 significance level and in 11 when using a 0.06 significance level. Second, the OIR-test is not rejected for any of the Stock Market Development regressions. This suggests that the legal origin dummies do not explain financial market development beyond their ability to explain crosscountry variation in the legal adaptability indicators. Third, the results on Property Rights are mixed. When controlling for Latitude and Independence, i.e., when controlling for other exogenous determinants of financial development, the OIR test is not rejected at the 0.05 level. This again suggests that legal origin does not explain property rights beyond the adaptability indicators. However, the OIR test is rejected in the property rights regressions when we do not control for Latitude and Independence. For the Private Credit regressions, the OIR test is always rejected, suggesting that legal origin explains Private Credit beyond the adaptability indicator. Since we believe (i) equity market development reflects securities market development more generally and (ii) securities market development requires more support from the legal system than bank development, we view these regressions as largely - though not without qualifications - consistent with the adaptability channel. 


\subsection{The Political and Adaptability Channels and Financial Development}

We now examine the political and adaptability channels simultaneously using an extended version of the instrumental variable procedure described above. Specifically, we estimate the following regression.

$\mathbf{1}^{\text {st }}$ Stage: Political Indicator $\quad=\delta_{1}[3$ legal Origin Dummies $]+\gamma_{1} X+v_{1}$

$\mathbf{1}^{\text {st }}$ Stage: Adaptability Indicator $=\delta_{2}[3$ legal Origin Dummies $]+\gamma_{2} X+v_{2}$

$2^{\text {nd }}$ Stage: Financial Development $=\alpha_{1}$ [Political Indicator $]+\alpha_{2}[$ Adaptability Indicator $]+\beta X+u$

Thus, we assess whether the exogenous components of the Political Indicator and the Adaptability Indicator explain financial development. Since there are two endogenous variables (Political Indicator and Adaptability Indicator) and three instruments (the three legal origin dummy variables), there is only one degree of freedom in the OIR test, i.e., the test of whether the instruments explain financial development beyond their ability to explain the endogenous variables.

To check the robustness of the results discussed below, we experimented with including other instrumental variables and various X-variables. Specifically, in the case when there are no included exogenous variables ( $\mathrm{X}$ is empty), we tried (a) using Latitude and Independence as instrumental variables and (b) using Latitude and Independence as instrumental variables and also including three variables measuring each country's religious composition as instrumental variables (i.e., the percentage of the population that is Catholic, Muslim, or a non-Protestant religion, so that Protestant is the omitted category). We get even stronger results than those reported below. Furthermore, we also included these additional instrumental variables in the second stage, i.e., we included them as Xvariables rather than as pure instruments. Again, we get even stronger results than those reported below.

Table 6 is organized in the following manner. There are four combinations of Political and Adaptability indicators for each financial development indicator. Thus, Table 6 reports the results of 
12 regressions. It also reports the test of the over-identifying restrictions (OIR test), and the F-test from the first-stage regressions. Table 6 is divided into three panels that report the Private Credit, Stock Market Development, and Property Rights regressions respectively.

The Table 6 regressions suggest that (1) legal origin explains financial development through the political and adaptability channels, and not through some third mechanism and (2) the evidence is more consistent with the adaptability channel than the political channel. In none of the 12 regressions is the OIR test rejected at the 10 percent level. Thus, we do not reject the null hypothesis that legal origin only explains financial development through the political and adaptability channels. ${ }^{14}$

In none of the 12 regressions does the political indicator enter significantly and with the sign predicted by the political channel. Theory suggests that the political indicators should enter positively. For instance, greater Tenure for Supreme Court Judges creates greater judicial independence and greater support for private property vis-à-vis the State and greater support for the private contractual arrangements underlying financial development. The political indicators sometimes enter negatively and significantly. This may occur if the predicted components of the political and adaptability channels are highly correlated. While we obtain the same results when adding many additional instrumental variables as specified above, we interpret the Table 6 results cautiously. Note these results do not imply that the political channel is in general unimportant. Rather, this paper's results are narrowly focused on assessing whether legal origin explains stock market development, property rights, and financial intermediary development through the political or adaptability channels.

The data support for the adaptability channel. The adaptability indicators always enter with the correct sign. Moreover, they enter significantly (at the 0.05 significance level) in 10 of the 12 
regressions. For example, Case Law is positively related with Private Credit, Stock Market Development, and Property Right when controlling for either of the political channel indicators.

We not only find a statistically significant relation between the exogenous component of legal adaptability and financial development, but also a large economic effect. Take the example of Case Law. According to the regressions in Table 6, countries in which judicial decisions are a source of law, have on average 130 percentage points higher levels of Private Credit and 52 percentage points higher levels of stock market development. Further, property rights protection is rated at least 2.6 points higher - on a five-point scale - in countries with case law. ${ }^{15}$ This is more than three standard deviations for Private Credit, more than two standard deviations for Property Rights and more than one standard deviation for Stock Market Development. 


\section{Conclusions}

While past work shows that legal origin helps explain financial development, this paper examines the mechanisms via which legal origin operates. The law and finance theory emphasizes two channels. The political channel postulates that legal traditions differ in terms of the priority they give to private property rights relative to the rights of the State. Since private property rights form the basis of financial development, historically determined differences in legal origin explain financial development today. The political channel holds that Civil law systems tend to promote the development of institutions that advance State power with negative implications for financial development. The adaptability channel stresses that legal traditions differ in terms of their responsiveness to changing socioeconomic conditions. Since inflexible legal traditions produce gaps between legal capabilities and commercial needs, historically determined differences in legal tradition explain financial development today. The adaptability channel holds that French legal origin countries are more likely to develop inefficiently rigid legal systems than British Common law and German civil law countries with adverse repercussions for financial development.

The results provide relatively more evidence for the adaptability channel than for the political channel. While subject to the qualifications emphasized in the Introduction, we find the following. First, the exogenous component of legal system adaptability explains cross-country differences in financial intermediary development, stock market development, and private property rights protection even when controlling for the political channel. Furthermore, the results are consistent with the view that legal origin does not explain financial market development beyond legal origin's ability to explain cross-country variability in legal system adaptability. Thus, the results suggest that legal origin matters because legal traditions differ in their ability to adjust efficiently to evolving socioeconomic conditions. Legal systems that adapt efficiently to minimize the gap between the 
financial needs of the economy and the legal system's capabilities will foster financial development more effectively than more rigid legal systems. Second, the exogenous component of the political channel does not explain cross-country variation in financial development. Third, German civil law and British common law countries have significantly better-developed financial intermediaries and markets and better property right protection than French civil law countries, which is fully consistent with the adaptability channel. In terms of policy implications, these tentative results advertise the benefits of efficient legal system adaptability. 
${ }^{1}$ Beck, Demirguc-Kunt, and Levine (2003) also confirm Acemoglu, Johnson, and Robinson's (2001, 2002) findings that geographical endowments affect the development of institutions, including financial institutions.

${ }^{2}$ Interestingly, Thomas Jefferson too sought to place the State above the judiciary, while John Marshall asserted judicial independence (Simon, 2002).

${ }^{3}$ For countervailing views and modifications, see Cooter and Kornhauser (1980), Cooter, Kornhauser, and Lane (1979), Blume and Rubinfeld (1982), Rubin (1982), and Kaplow (1992), Coffee (2000).

${ }^{4}$ See, for instance, Rubin (1977, 1982), Priest (1977), and Bailey and Rubin (1994).

${ }^{55}$ Rajan and Zingales (2003) and Pagan and Volpin (2001) stress that contemporaneous political factors influence financial markets. The law and finance theory's political channel is related, though distinct. It stresses that the civil law has promoted the development of institutions that further the power of the State, which hinders financial development.

${ }^{6}$ England did not try to replace Islamic, Hindu, or unwritten African law and the flexibility of the Common law eased its transfer. For instance, the English courts in India were instructed to apply Islamic or Hindu law depending on the faith of the parties in cases of inheritance, marriage, caste, etc. In Africa, judges were to apply the English law only to the extent that local circumstances permitted and matters were to be decided by equity and good conscience as rendered necessary by local circumstances $(\mathrm{ZK}, 1998,225-9)$. While somewhat chaotic, this arguably set the stage for the evolution of an independent, dynamic common law in the post-colonial era.

${ }^{7}$ For an insightful analysis of the transfer of the law internationally and its effect on economic development, see Berkowitz, Pistor, and Richard (2002)

${ }^{8}$ It is not necessarily the case that the case law responds more effectively than statutory changes. For instance, as exemplified by the law on contracts for the benefit of third parties, English law has clung with remarkable tenacity to the principle that 'only a person who is a party to a contract can sue on it'." (ZK. 1998, 468) In contrast, the Continental countries granted greater rights to third parties through statutory changes. For a fascinating comparison of the laws of incorporation and partnerships in the United States and French, see Lamoreaux and Rosenthal (2002).

${ }^{9}$ Zweigert and Kotz $(1998,158)$ argue that the unlike in France, the German civil code grants greater discretion to judges, “... the courts in Germany have relied above all on the general clauses of Art. 138, 157, 242, and 826." 
${ }^{10}$ One could argue that (i) adaptability is crucial, (ii) Common law countries tend be more flexible than Civil law countries, and (iii) reject the view that German civil law systems tend to adapt more efficiently than French civil law systems. We assess this empirically below.

${ }^{11}$ Djankov, La Porta, Lopez-de-Silanes and Shleifer (2003) use survey data from law firms in 109 countries to construct indicators of the functioning of the legal system when courts confront cases involving the eviction of tenants for nonpayments of rent and the collection of bounced check.

${ }^{12}$ According to the endowment theory (Engerman and Sokoloff, 1997; Acemoglu, Johnson, and Robinson, 2001), the geographical endowments encountered by Europeans determined their colonization strategies. According to Acemoglu, Johnson, and Robinson (2001), in areas with more favorable disease environments, Europeans founded settler colonies, whereas in others they established extractive colonies. Settler colonies developed long-lasting institutions that protect private property rights and are thus conducive to the development of financial markets. Extractive colonies instead developed long-lasting institutions that allow the few elite to exploit their positions, with adverse implications for private property rights (Easterly and Levine, 2003). Since countries that are closer to the equator tend to have unfavorable disease endowments, we use latitude as an exogenous proxy of geographical endowments. In our previous work we also used settler mortality, the log of death per thousand soldiers as an indicator of the initial disease environment. However, this indicator is only available for former colonies. Beck, Demirguc-Kunt, and Levine (2003), however, show that using latitude as indicator of initial endowments leads to similar conclusions.

${ }^{13}$ This produces a Lagrange multiplier test statistic that under the null hypothesis is distributed Chi-squared (m), where $\mathrm{m}$ is the number of overidentifying restrictions. The number of overidentifying restrictions equals the number of excluded exogenous variables minus the number of endogenous variables included as regressors in the second stage regression.

${ }^{14}$ These results hold when controlling for other potential exogenous determinants of financial development, such as the degree of ethnic diversity (Easterly and Levine, 1997).

${ }^{15}$ These numbers are based on the smallest coefficient estimates for each financial development indicator. 


\section{References}

Acemoglu, Daron, Johnson, Simon, and Robinson, James A., "The Colonial Origins of Comparative

Development: An Empirical Investigation.” American Economic Review 91, 1369-1401, 2001.

Acemoglu, Daron, Johnson, Simon, and Robinson, James A., "Reversal of Fortunes: Geography and Institutions in the Making of the Modern World Income Distribution." Quarterly Journal of Economics 117, forthcoming 2002.

Bailey, Martin J., Rubin, Paul H., "A Positive Theory of Legal Change." International Review of Law and Economics 14, 467-477, 1994.

Beck, Thorsten, Demirgüç-Kunt, Asli, and Levine, Ross, "Law, Endowments, and Finance." Journal of Financial Economics, forthcoming, 2003.

Beck, Thorsten, and Levine, Ross, "Industry Growth and Capital Allocation: Does Having a Market- or Bank-Based System Matter?” Journal of Financial Economics 64, 147-180, 2002.

Beck, Thorsten, and Levine, Ross, "Stock Markets, Banks, and Economic Growth: Panel Evidence.” Journal of Banking and Finance, forthcoming, 2003.

Berkowitz, Daniel, Pistor, Katharina, and Richard, Jean Francois, "Economic Development, Legality, and the Transplant Effect.” European Economic Review, forthcoming, 2002.

Blume, Lawrence E., Rubinfeld, Daniel L., "The Dynamics of the Legal Process.” Journal of Legal Studies 11, 405-419, 1982.

Claessens, Stijn, Laeven, Luc, "Financial Development, Property Rights, and Growth.” Journal of Finance, forthcoming, 2003.

Coffee, John C., "Privatization and Corporate Governance: The Lessons from the Securities Market Failure." Unpublished working paper 158. Columbia Law School, New York, 2000. 
Cooter, Robert, Kornhauser, Lewis, “Can Litigation Improve the Law Without the Help of Judges?” Journal of Legal Studies 9, 139-63, 1980.

Cooter, Robert, Kornhauser, Lewis, and Lane, David, "Liability Rules, Limited Information and the Role of Precedent.” Bell Journal of Economics 10, 366-81, 1979.

Damaska, Mirjan R., The Faces of Justice and State Authority: A Comparative Approach to the Legal Process, New Haven, CT: Yale University Press, 1986.

Dawson, John P., The Oracles of the Law. Ann Arbor, MI: University of Michigan Law School (Reprinted in 1986 by William S. Hein \& Co., Inc. Buffalo, New York), 1968.

Dawson, John P., A History of Lay Judges. Cambridge, MA: Harvard University Press, 1960.

Demirgüç-Kunt, Asli and Vojislav Maksimovic, "Law, Finance and Firm Growth." Journal of Finance 53, 2107-2137, 1998.

Demirgüç-Kunt, Asli and Vojislav Maksimovic, "Institutions, Financial Markets and Firm Debt Maturity" Journal of Financial Economics, 54, 295-336, 1999.

Djankov, Simeon, La Porta, Rafael, Lopez-de-Silanes, Florencio, and Shleifer, Andrei, "The Practice of Justice." Quarterly Journal of Economics, 2003, forthcoming.

Easterly, William and Levine, Ross, “Africa's Growth Tragedy: Policies and Ethnic Divisions." Quarterly Journal of Economics 112, 1203-50, 1997.

Easterly, William, and Levine, Ross, “Tropics, Germs, and Crops: How Endowments Influence Economic Development." Journal of Monetary Economics, 2003, forthcoming.

Engerman, Stanley, and Sokoloff, Kenneth, "Factor Endowments, Institutions, and Differential Paths of Growth among New World Economies.” In S.H. Haber, S.H. Ed., How Latin America Fell Behind, pp. 260-304, Stanford CA: Stanford University Press, 1997.

Glaeser, Edward, and Shleifer, Andrei, "Legal Origins.” Quarterly Journal of Economics, forthcoming, 
November, 117, 2002.

Hayek, Friedrich, The Constitution of Liberty. Chicago, IL: The University of Chicago Press, 1960.

Himmelberg, Charles, Hubbard, R. Glenn, and Love, Inessa, "Investor Protection, Ownership, and the Cost of Capital.” World Bank Working Paper Series No. 2834, Washington, D.C.: World Bank, 2002.

Johnson, Simon, Boone, Peter, Breach, Alasdair, and Friedman, Eric, "Corporate Governance in the Asian Financial Crisis.” Journal of Financial Economics 58, 141-186, 2000.

Kaplow, Louis, “Rules versus Standards: An Economic Analysis.” Duke Law Journal 42, 557-629, 1992.

Keinan, Yoram, "The Evolution of Secured Transactions." Unpublished working paper, University of Michigan Law School, 2000.

King, Robert G. and Levine, Ross, "Finance and Growth: Schumpeter Might Be Right." Quarterly Journal of Economics 108, 717-38, 1993a.

King, Robert G. and Levine, Ross, “Finance, Entrepreneurship, and Growth: Theory and Evidence.” Journal of Monetary Economics 32, 513-42, 1993b.

Lamoreaux, Naomi and Rosenthal, Jean-Laurent, "Organizational Choice and Economic Development: A Comparison of France and the United States During the mid- $19^{\text {th }}$ Century." University of California at Los Angeles mimeo, 2002.

La Porta, Rafael, Lopez-de-Silanes, Florencio, Pop-Eleches, Christian, and Shleifer, Andrei, “The Guarantees of Freedom." Unpublished working paper, Harvard University, 2002b.

La Porta, Rafael, Lopez-de-Silanes, Florencio, Shleifer, Andrei, and Vishny, Robert W., "Investor Protection and Corporate Valuation." Journal of Finance 57, 1147-1170, 2002a.

La Porta, Rafael, Lopez-de-Silanes, Florencio, Shleifer, Andrei, and Vishny, Robert W., "The Quality of Government." Journal of Law, Economics, and Organization 15, 222-279, 1999.

La Porta, Rafael, Lopez-de-Silanes, Florencio, Shleifer, Andrei, and Vishny, Robert W., "Law and Finance." 
Journal of Political Economy 106, 1113-1155, 1998.

Levine, Ross, "Financial Development and Economic Growth: Views and Agenda.” Journal of Economic Literature 35, 688-726, 1997.

Levine, Ross, "The Legal Environment, Banks, and Long-run Economic Growth.” Journal of Money, Credit, and Banking 30, 688-726, 1998.

Levine, Ross, "Law, Finance, and Economic Growth.” Journal of Financial Intermediation 8, 36-67, 1999. Levine, Ross, Loayza, Norman, and Beck, Thorsten, "Financial Intermediation and Growth: Causality and Causes.” Journal of Monetary Economics 46, 31-77, 2000.

Levine, Ross, and Zervos, Sara, "Stock Markets, Banks and Economic Growth." American Economic Review 88, 537-58, 1998.

Mahoney, Paul G., "The Common Law and Economic Growth: Hayek Might be Right.” Journal of Legal Studies 30, 503-525, 2001.

Merryman, John Henry, The Civil Law Tradition: An Introduction to the Legal Systems of Western Europe and Latin America. Stanford, CA: Stanford University Press, 1985.

Merryman, John Henry, “The French Deviation.” The American Journal of Comparative Law 44, 109-119, 1996.

Morck, Randall Yeung, Bernard, and Yu, Wayne, "The Information Content of Stock Markets: Why do Emerging Markets have Synchronous Price Movements?” Journal of Financial Economics 58, 215$260,2000$.

North, Douglass, "Institutions, Economic Growth and Freedom: An Historical Introduction.” In M.A. Walker, Ed., Freedom, Democracy and Economic Welfare, Vancouver: Fraser Institute, 1988. North, Douglass, and Weingast, Barry R., "Constitutions and Commitment: The Evolution of Institutions Governing Public Choice in Seventeenth-Century England." Journal of Economic History 49, 803- 
$832,1989$.

Pagano, Marco., and Volpin, Paolo, “The Political Economy of Finance.” Oxford Review of Economic Policy 17, 502-519, 2001.

Pistor, Katharina, Keinan, Yoran, Kleinheisterkamp, Jan, and West, Mark D., “The Evolution of Corporate Law.” Unpublished working paper, Harvard University (Kennedy School of Government), 2000.

Pistor, Katharina, Keinan, Yoran, Kleinheisterkamp, Jan, and West, Mark D., "Innovation in Corporate Law: A Comparative Analysis of Ten Jurisdictions." Journal of Comparative Economics, 2003.

Priest, George L., "The Common Law Process and the Selection of Efficient Rules.” Journal of Legal Studies 6, 65-82, 1977.

Posner, Richard A., Economic Analysis of the Law. Boston, MA: Little-Brown, 1973..

Rajan, Raghuram G., and Zingales, Luigi, “The Great Reversals: The Politics of Financial Development in the $20^{\text {th }}$ Century." Journal of Financial Economics, forthcoming, 2003.

Rubin, Paul H., "Why is the Common Law Efficient?" Journal of Legal Studies 6, 51-64, 1977.

Rubin, Paul H., “Common Law and Statute Law.” Journal of Legal Studies 11, 205-33, 1982.

Stulz, Rene, and Williamson, Rohan, "Culture, Openness, and Finance." Journal of Financial Economics, forthcoming, 2003.

Simon, James F., What Kind of Nation: Thomas Jefferson, John Marshall, and the Epic Struggle to Create the United States. New York, NY: Simon \& Schuster, 2002.

Wurgler, Jeffrey, "Financial Markets and the Allocation of Capital." Journal of Financial Economics 58, 187-214, 2000.

Zweigert, Konrad, and Kötz, Hein, Introduction to Comparative Law. New York, NY: Oxford University Press, 1998. 

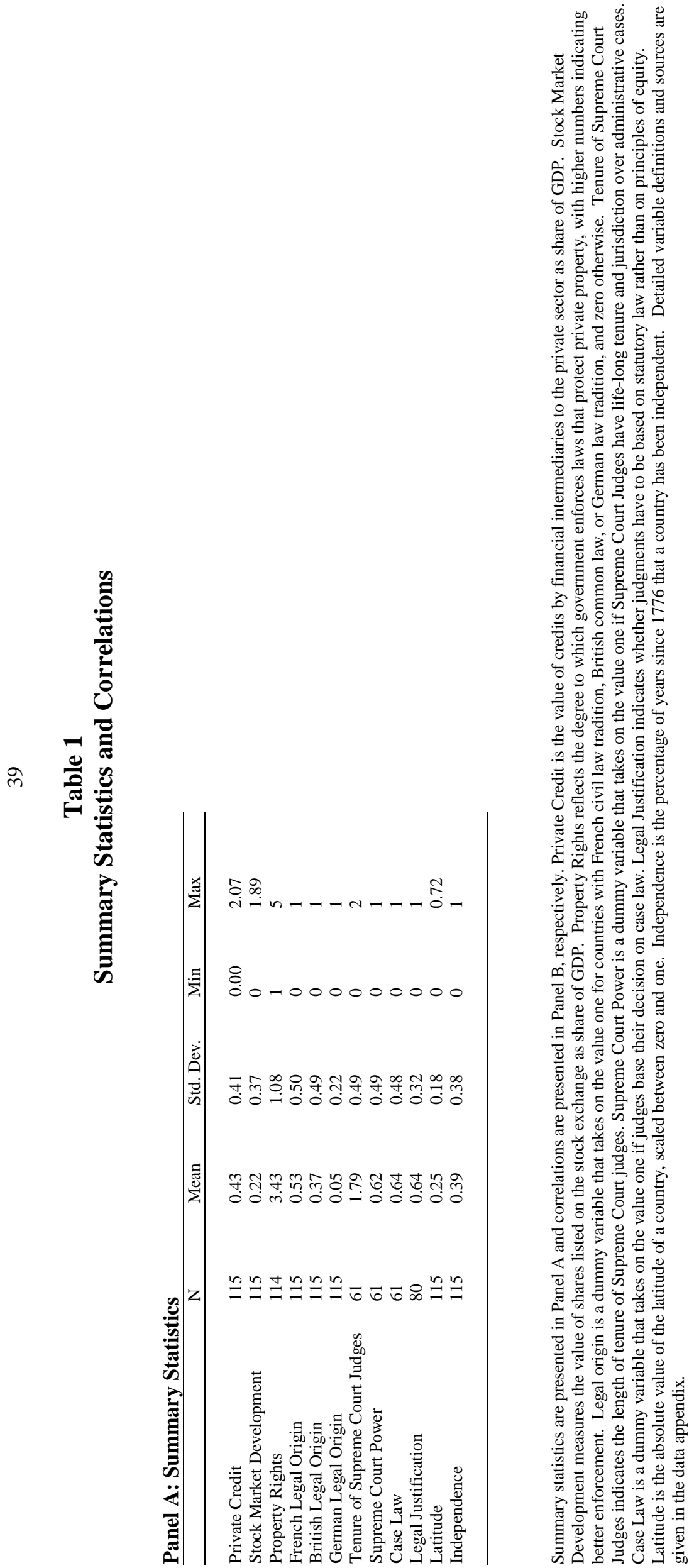


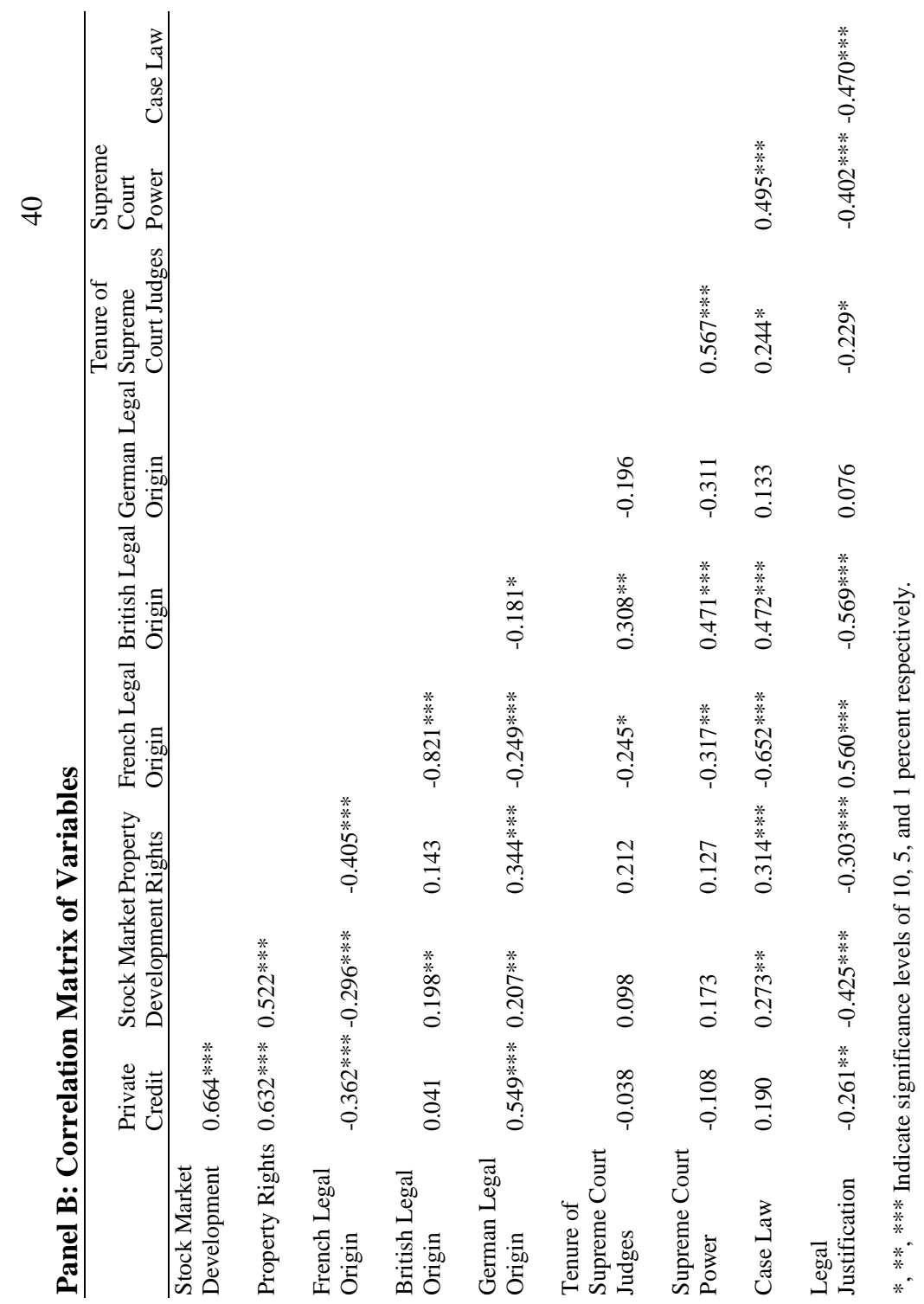




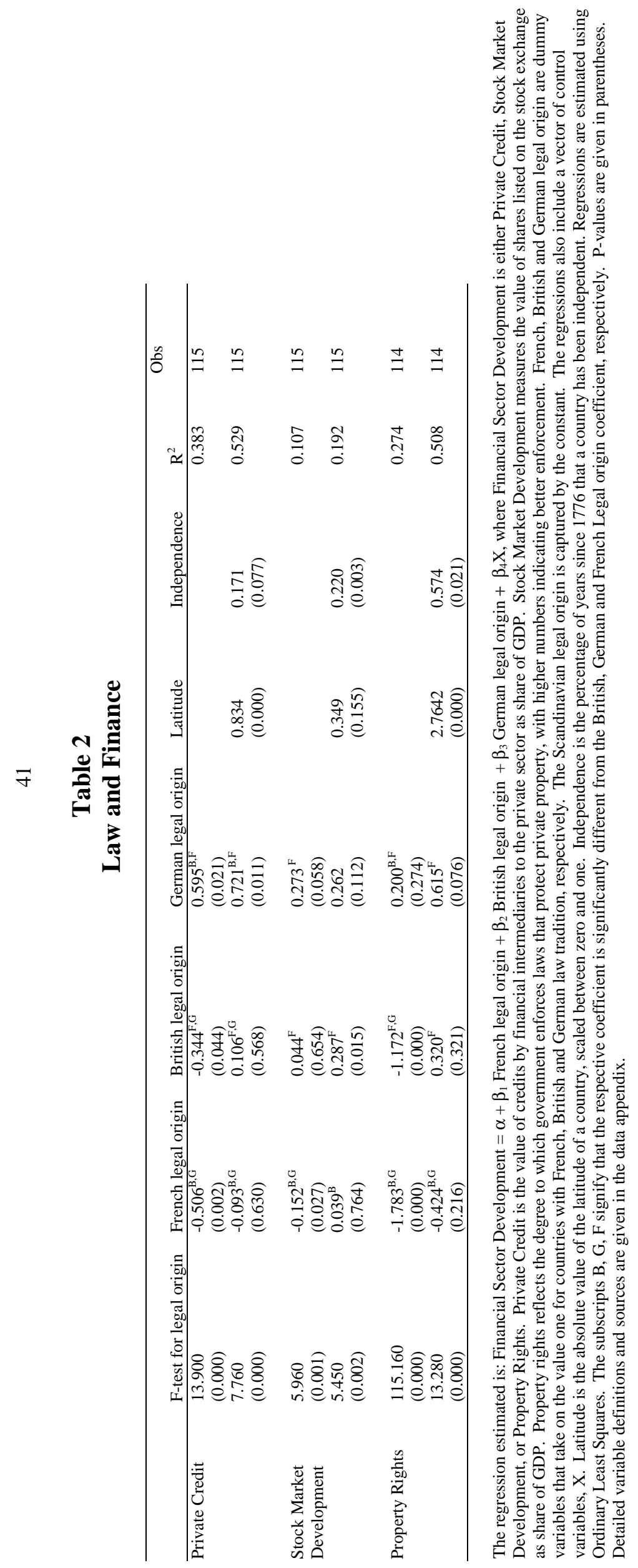




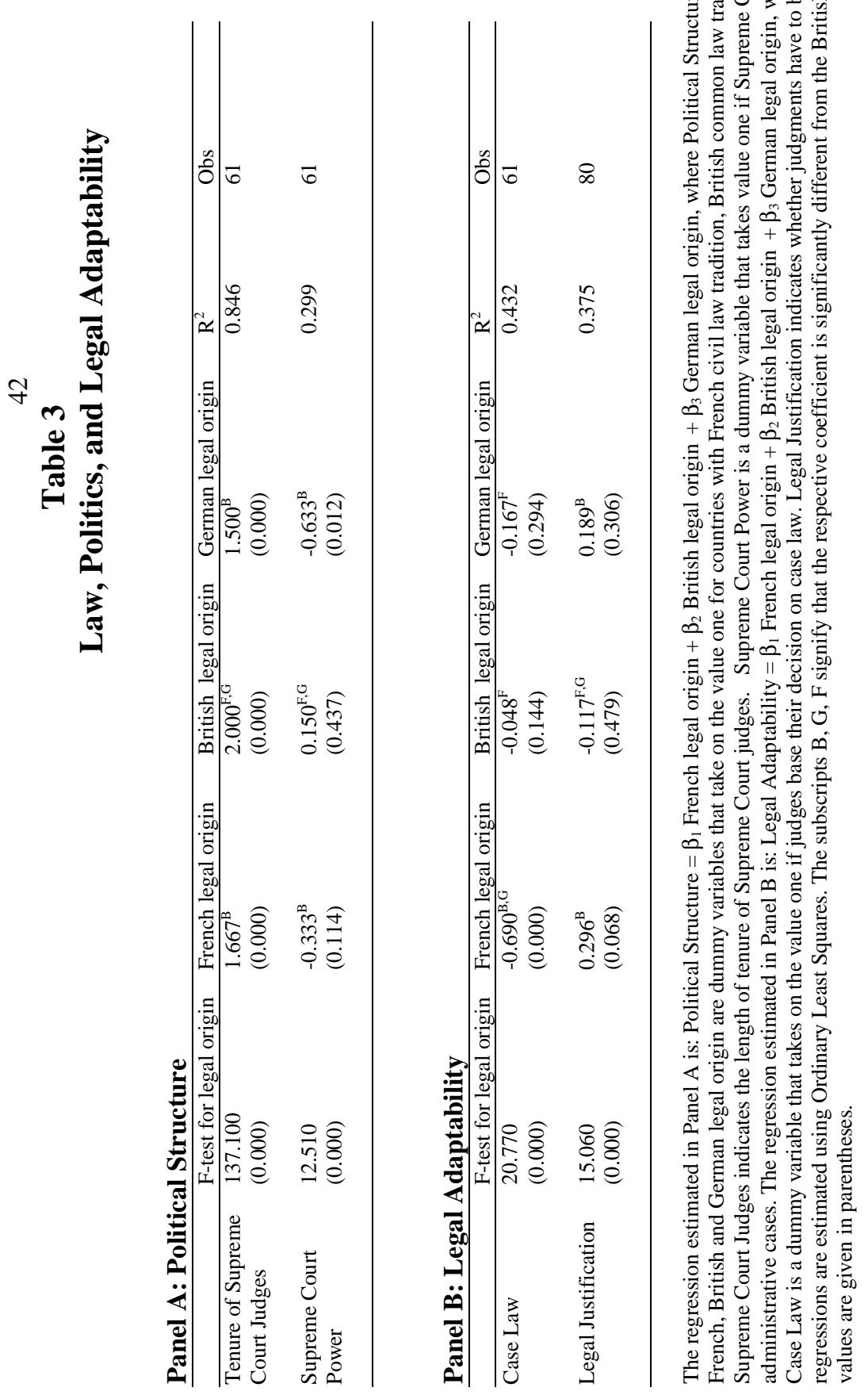




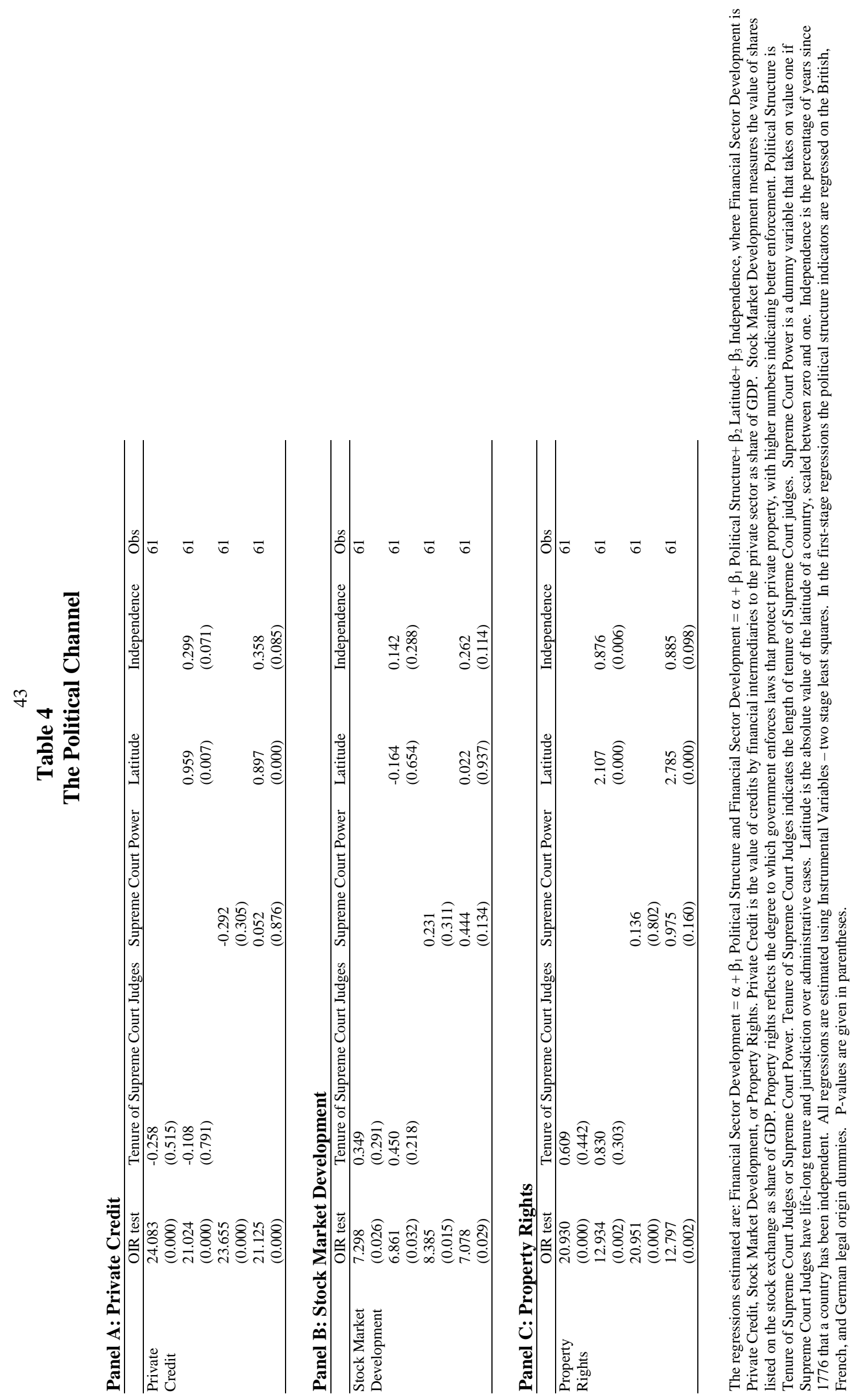




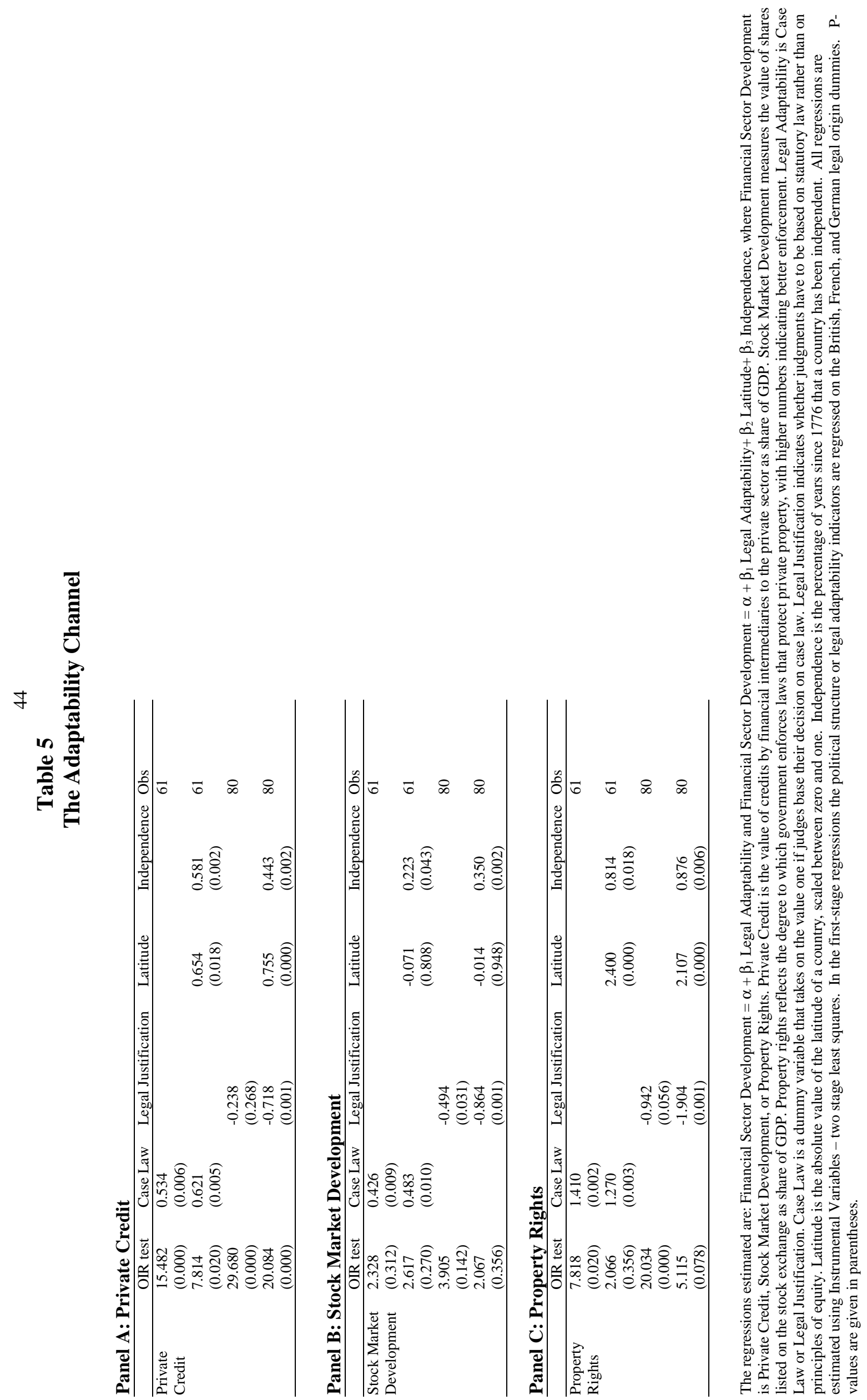


Table 6 Finance, Politics, and Legal Adaptability: The Horse Race

Panel A: Private Credit

\begin{tabular}{|c|c|c|c|c|c|c|c|}
\hline \multicolumn{2}{|c|}{ Adaptability Indicators } & \multicolumn{2}{|c|}{ Political Power Indicators } & & \multicolumn{2}{|c|}{ First-stage F-tests } & \multirow[b]{2}{*}{ Obs } \\
\hline Case Law & $\begin{array}{l}\text { Legal } \\
\text { Justification }\end{array}$ & $\begin{array}{l}\text { Tenure of } \\
\text { Supreme } \\
\text { Court Judges }\end{array}$ & $\begin{array}{l}\text { Supreme Court } \\
\text { Power }\end{array}$ & OIR test & Adaptability & $\begin{array}{l}\text { Political } \\
\text { Power }\end{array}$ & \\
\hline $\begin{array}{l}1.472 \\
(0.045)\end{array}$ & & $\begin{array}{l}-1.993 \\
(0.088)\end{array}$ & & $\begin{array}{l}0.117 \\
(0.732)\end{array}$ & $\begin{array}{l}13.090 \\
(0.000)\end{array}$ & $\begin{array}{l}3.390 \\
(0.024)\end{array}$ & 59 \\
\hline $\begin{array}{l}1.347 \\
(0.002)\end{array}$ & & & $\begin{array}{l}-1.292 \\
(0.007)\end{array}$ & $\begin{array}{l}0.000 \\
(0.998)\end{array}$ & & $\begin{array}{l}8.920 \\
(0.000)\end{array}$ & 59 \\
\hline & $\begin{array}{l}-1.691 \\
(0.101)\end{array}$ & $\begin{array}{l}-2.464 \\
(0.071)\end{array}$ & & $\begin{array}{l}0.833 \\
(0.361)\end{array}$ & $\begin{array}{l}14.800 \\
(0.000)\end{array}$ & $\begin{array}{l}3.130 \\
(0.034)\end{array}$ & 54 \\
\hline & $\begin{array}{l}-2.138 \\
(0.027)\end{array}$ & & $\begin{array}{l}-1.909 \\
(0.004)\end{array}$ & $\begin{array}{l}0.317 \\
(0.573)\end{array}$ & & $\begin{array}{l}7.250 \\
(0.000)\end{array}$ & 54 \\
\hline
\end{tabular}

\section{Panel B: Stock Market Development}

\begin{tabular}{|c|c|c|c|c|c|c|c|}
\hline \multicolumn{2}{|c|}{ Adaptability Indicators } & \multicolumn{2}{|c|}{ Political Power Indicators } & & \multicolumn{2}{|c|}{ First-stage F-tests } & \multirow[b]{2}{*}{ Obs } \\
\hline Case Law & $\begin{array}{l}\text { Legal } \\
\text { Justification }\end{array}$ & $\begin{array}{l}\text { Tenure of } \\
\text { Supreme } \\
\text { Court Judges }\end{array}$ & $\begin{array}{l}\text { Supreme Court } \\
\text { Power }\end{array}$ & OIR test & Adaptability & $\begin{array}{l}\text { Political } \\
\text { Power }\end{array}$ & \\
\hline \multirow{8}{*}{$\begin{array}{l}0.589 \\
(0.046) \\
0.525 \\
(0.032)\end{array}$} & & -0.374 & & 1.007 & 13.090 & 3.390 & 59 \\
\hline & & $(0.421)$ & & $(0.316)$ & $(0.000)$ & $(0.024)$ & \\
\hline & & & -0.179 & 1.597 & & 8.920 & 59 \\
\hline & & & $(0.502)$ & $(0.206)$ & & $(0.000)$ & \\
\hline & -0.953 & -0.788 & & 0.158 & 14.800 & 3.130 & 54 \\
\hline & $(0.033)$ & $(0.176)$ & & $(0.691)$ & $(0.000)$ & $(0.034)$ & \\
\hline & -1.002 & & -0.514 & 0.627 & & 7.250 & 54 \\
\hline & $(0.026)$ & & $(0.166)$ & $(0.429)$ & & $(0.000)$ & \\
\hline
\end{tabular}

\section{Panel C: Property Rights}

\begin{tabular}{|c|c|c|c|c|c|c|c|}
\hline \multicolumn{2}{|c|}{ Adaptability Indicators } & \multicolumn{2}{|c|}{ Political Power Indicators } & & \multicolumn{2}{|c|}{ First-stage F-tests } & \multirow[b]{2}{*}{ Obs } \\
\hline Case Law & $\begin{array}{l}\text { Legal } \\
\text { Justification }\end{array}$ & $\begin{array}{l}\text { Tenure of } \\
\text { Supreme } \\
\text { Court Judges }\end{array}$ & $\begin{array}{l}\text { Supreme Court } \\
\text { Power }\end{array}$ & OIR test & Adaptability & $\begin{array}{l}\text { Political } \\
\text { Power }\end{array}$ & \\
\hline \multirow{8}{*}{$\begin{array}{l}2.759 \\
(0.027) \\
2.678 \\
(0.002)\end{array}$} & & -2.683 & & 0.776 & 13.090 & 3.390 & 59 \\
\hline & & $(0.173)$ & & $(0.378)$ & $(0.000)$ & $(0.024)$ & \\
\hline & & & -1.878 & 0.675 & & 8.920 & 59 \\
\hline & & & $(0.041)$ & $(0.411)$ & & $(0.000)$ & \\
\hline & -2.578 & -3.087 & & 2.527 & 14.800 & 3.130 & 54 \\
\hline & $(0.106)$ & $(0.142)$ & & $(0.112)$ & $(0.000)$ & $(0.034)$ & \\
\hline & -3.407 & & -2.667 & 1.798 & & 7.250 & 54 \\
\hline & $(0.037)$ & & $(0.050)$ & $(0.180)$ & & $(0.000)$ & \\
\hline
\end{tabular}

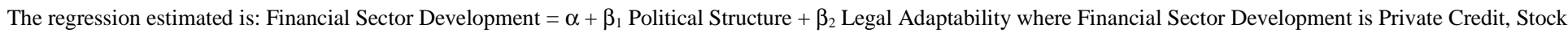

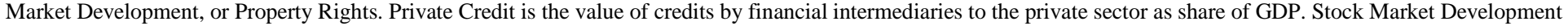

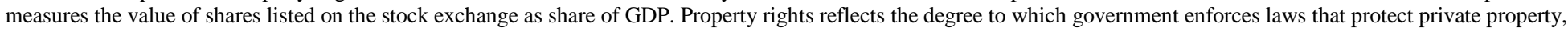

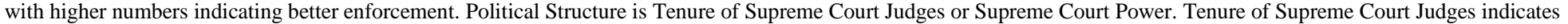

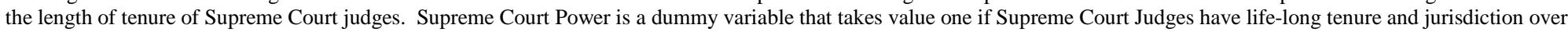

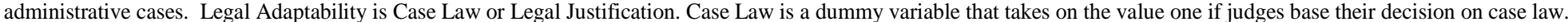

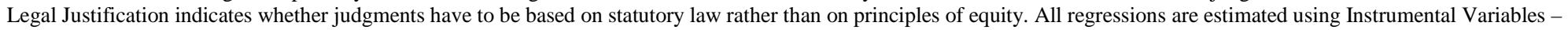

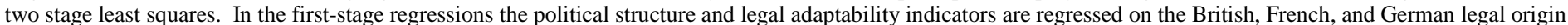
dummies. (F-test results for the first stage regressions are presented, as well). P-values are in parentheses. 